\title{
Mesozooplankton communities in the Magellan region*
}

\author{
KATJA DEFREN-JANSON ${ }^{1}$, SIGRID B. SCHNACK-SCHIEL ${ }^{1 \dagger}$ and CLAUDIO RICHTER ${ }^{2}$
}

${ }^{1}$ Alfred-Wegener-Institut für Polar- und Meeresforschung, 27515 Bremerhaven, Germany. ${ }^{2}$ Institut für Polarökologie, 24148 Kiel, Germany, present address: Zentrum für Marine Tropenökologie, 28359 Bremen, Germany.

\begin{abstract}
SUMMARY: During the Joint Chilean-German-Italian Magellan "Victor Hensen” Campaign in November 1994 zooplankton sampling was carried out by means of a multiple opening-closing multinet equipped with $300 \mu \mathrm{m}$ mesh size. Distribution pattern was studied and community analyses of mesozooplankton were made at seven stations in the Magellan region. Highest numbers of individuals were found in the northern part of the investigation area (Magdalena to Brecknock Channels) at stations with a mixed water column. In the southern part (Beagle and Ballenero Channels), lower zooplankton abundances were associated with a stratified water column due to melt water from several glaciers. At all stations holoplankton dominated the assemblages $(83-97 \%)$. Copepods were by far the most abundant taxon encountered during this study, contributing to more than $2 / 3$ of the total zooplankton numbers. They occurred throughout the water column with maxima in middle water layers. Appendicularians ranked second in abundance with their main distribution in the upper $100 \mathrm{~m}$. Euphausiids were found in higher densities only in the Magdalena Channel (St. 1313); their vertical distribution pattern resembled that of copepods. Cladocerans aggregated at all stations in the upper $30 \mathrm{~m}$. Within the meroplankton, echinoderm larvae were most abundant, notably in the upper $100 \mathrm{~m}$ under stratified conditions. Cluster analysis separated between a surface community covering all stations, and a northern and southern deep community, respectively.
\end{abstract}

Key words: Mesozooplankton, communities, distribution, abundance, Magellan region

RESUMEN: COMUNIDADES MESOZOOPLANCTÓNICAS EN LA REGIÓN DE MAGALLANES. - Durante la campaña Chileno-GermanoItaliana Magallánica con el "Victor Hensen" en Noviembre 1994, se muestreó el zooplancton en la región de Magallanes con una red de apertura-cerradura "multinet" equipada con una malla de $300 \mu \mathrm{m}$. Se investigaron la distribución y las comunidades del zooplancton en 7 estaciones. Las más altas concentraciones de individuos se encontraron en aguas poco estratificadas en la parte norte del área de estudio entre el Canal de Magdalena y el Canal de Brecknock. Más al sur, en los Canales del Beagle y Ballenero, se encontraron menores densidades de zooplancton en condiciones estratificadas, sometidas a un aporte de agua dulce proveniente de los numerosos glaciares. El holoplancton dominaba $(83-97 \%)$ las asociaciones. Los copépodos fueron el taxón más abundante, contribuyendo con más de dos tercios al número total del zooplancton. Los copépodos estaban repartidos por toda la columna de agua, con un máximo en profundidades intermedias. El siguiente grupo más abundante fue el de las apendicularias, con concentraciones más importantes en los $100 \mathrm{~m}$ bajo la superficie. Solamente en el Canal de Magdalena (estación 1313) se encontraron altas densidades de eufáusidos. Su distribución vertical era similar a la de los copépodos. Los cladóceros se encontraron en agregaciones a $30 \mathrm{~m}$ de profundidad. En el meroplancton, las larvas de equinodermos dominaban, con concentraciones más altas en la capa superficial $(0-100 \mathrm{~m})$ bajo condiciones estratificadas. Mediante análisis de clusters se pudieron separar tres comunidades: una comunidad superficial repartida por toda la región del estudio, una comunidad profunda de la parte norte, y otra de la parte sur.

Palabras clave: Mesozooplancton, comunidades, distribución, abundancia, región de Magallanes.

This is AWI contr. no. 1745

"corresponding author

*Accepted December 28, 1999. 


\section{INTRODUCTION}

The narrow fjord system of the Magellan region, influenced by Atlantic water masses in the east and by Pacific waters in the west, is closely linked to the Antarctic ecosystem (e.g. Guglielmo et al., 1993). Various shallow sills at the entrance of the fjord system reduce the intrusion of open oceanic water and plankton (Antezana et al., 1992). Antezana (1999a) divided the study area along the Magellan-Beagle passage into four microbasins with an important exchange occurring between the basins (Antezana, 1999b). Mainly in the vicinity of the Beagle Channel, numerous glaciers reach the sea, and ice-melt lowers the salinity (Antezana, 1999 a). Due to smallscale differences in bathymetry and water characteristics plankton organisms living in the fjords are subjected to a highly variable environment. This variability constrains the survival of the plankton to the most widely adapted species.

Only few studies deal with zooplankton in the Magellan region and most of them are cruise or workshop reports (Ghirardelli et al., 1991; Guglielmo et al., 1991; 1993; Mazzocchi and Ianora, 1991; Antezana et al., 1992; Benassi et al., 1994; Antezana et al.; 1996; Pagès, 1996). Recently, two excellent atlases of dominant zooplankton taxa of the Straits of Magellan were published (Mazzocchi et al., 1995; Guglielmo et al., 1996).
The aim of this study is to briefly describe mesozooplankton communities in different basins of the Magellan region characterized by differing environmental conditions.

\section{MATERIAL AND METHODS}

Zooplankton samples were collected with a 300 $\mu \mathrm{m}$ mesh multiple opening-closing multinet during the Magellan cruise of RV "Victor Hensen" in November 1994. Daytime vertical hauls were conducted between 100 and $400 \mathrm{~m}$ maximum wire length depending on bathymetry, covering standard depth intervals. Samples were preserved in $4 \%$ borax-buffered formaldehyde seawater solution. In the laboratory, the samples were split into two. Onehalf of the samples was sorted to the taxonomic level of order (and above) and counted. Euphausiids were enumerated according to their developmental stages. The filtered volume was calculated by multiplying the vertical distance of the tow by the mouth area of the multinet $\left(0.25 \mathrm{~m}^{2}\right)$ assuming $100 \%$ filtering efficiency. In this manuscript the mesozooplankton obtained at seven stations located between the Beagle Channel and the Magdalena Channel (Fig. 1) is described.

Statistical analyses were performed with the PRIMER programs (Plymouth Routines in Multi-

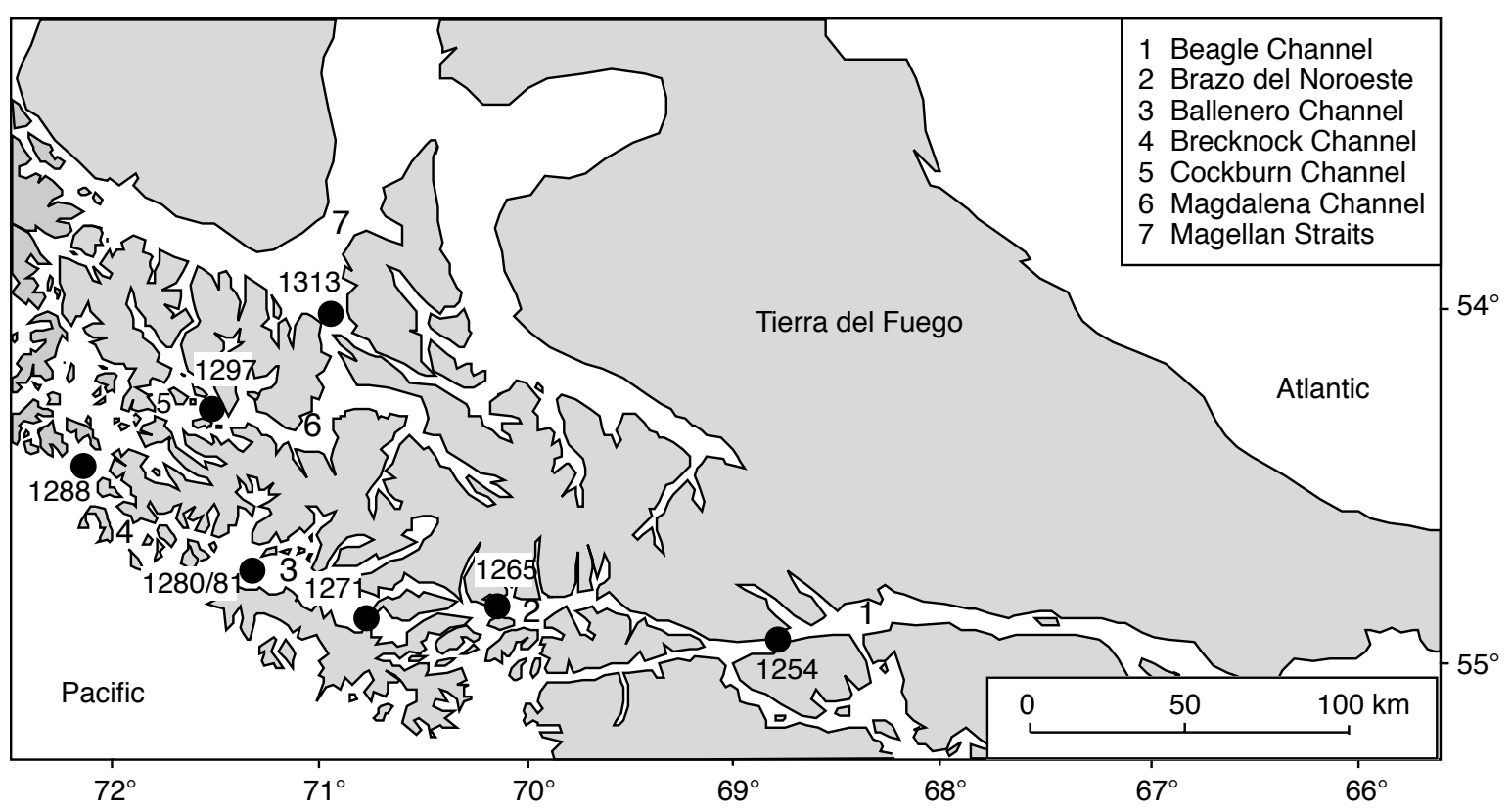

FIG. 1. - Locations of sampling stations in the Magellan region. 
variate Ecological Research) developed at Plymouth Marine Laboratory. Hierarchical agglomerative clustering was applied to differentiate mesozooplankton communities using the Bray-Curtis Index which groups the samples according to both presence and abundance. The matrix of similarities was used to test for vertical differences between samples. The complete linkage method was used in order to obtain strong separations of the groupings.

\section{RESULTS}

At all stations the numerical dominance of holoplankton is overwhelming, accounting for 83 to $97 \%$ of the total abundance of individuals. Within the holoplankton copepods were by far the most abundant taxon contributing between 72 to $94 \%$. Appen- dicularians ranked second (2-20\%), followed by euphausiids $(2-7 \%)$ and cladocerans $(<1-11 \%)$. Chaetognaths and ostracods occurred at all stations but only in low numbers $\left(<3\right.$ Ind. $\left.\mathrm{m}^{-3}\right)$. Echinoderm larvae dominated the meroplankton (20-65\%), followed by larvae of cirripedes $(6-20 \%)$, polychaetes (7-40\%) and bryozoans (1-22\%).

The lowest stocks of holoplankton were found in the southern part in the vicinity of the Beagle and Ballenero Channels (Sts. 1254-1280/81), high densities occurred at the northern stations in the Brecknock, Cockburn and Magdalena Channels (Sts. 1288-1313, Fig. 2). The meroplankton, which holds similar shares of the plankton throughout the study area, lacks a clear regional distribution pattern. The lowest stock of individuals was encountered at St. 1280/81, the highest at the nearby St. 1288. At station 1271, situated in

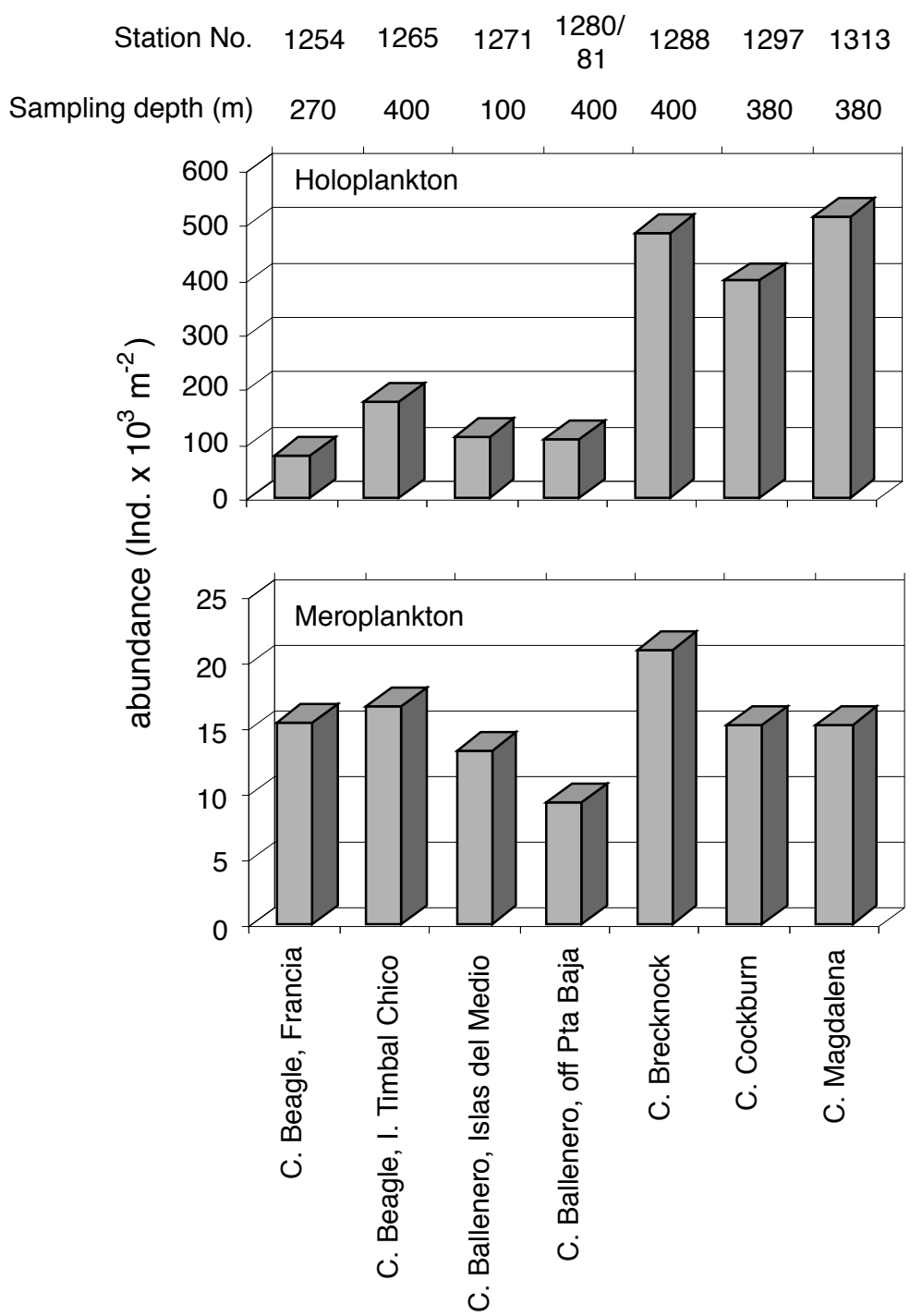

FIG. 2. - Abundance (Ind. $\mathrm{m}^{-2}$ ) of holoplankton and meroplankton. 
Stat. No.

$1254126512711280 / 128812971313$

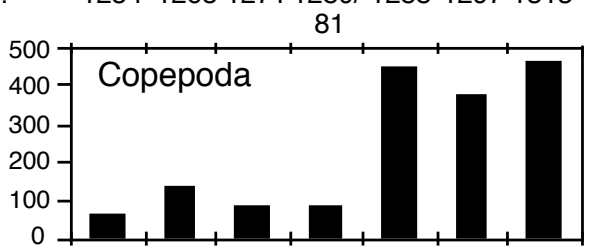

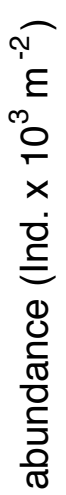
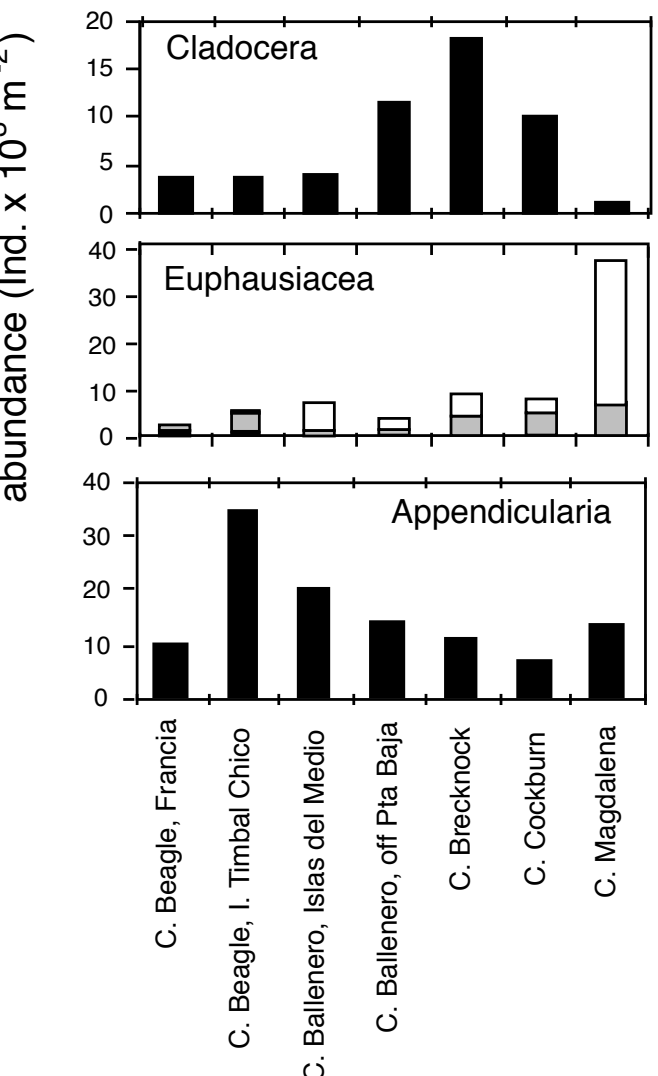

Euphausiacea nauplii

Euphausiacea calyptopis

Euphausiacea furciliae
$1254126512711280 / 128812971313$

81
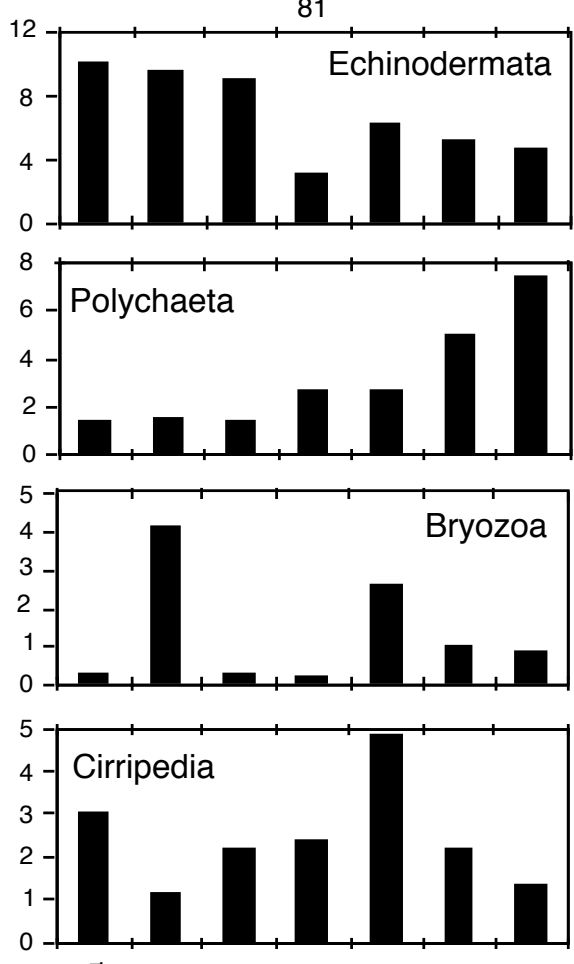

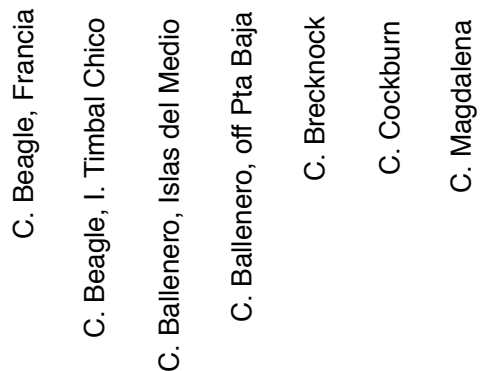

FIG . 3. - Abundance (Ind. $\mathrm{m}^{-2}$ ) of copepods, cladocerans, euphausiids, appendicularians and larvae of echinoderms, polychaetes, bryozoans and cirripedes.

the transition area between the Brazo del Noroeste and the Ballenero Channel, similar standing stocks of holo- and meroplankton were distributed over a much shallower water column (132 $\mathrm{m}$ deep) giving rise to 4 -fold higher concentrations of individuals on a volumetric basis (Ind. $\mathrm{m}^{-3}$, not shown) than the surrounding stations in the south.

Due to their great dominance, the distribution pattern of copepods reflects that of the total holoplankton (Fig. 3). Total euphausiid concentrations show little regional variability, except for St. 1313 where we encountered high numbers of furcilia stages. Euphausiid nauplii were present mainly at the southern stations, however, the overall abundance was low. Calyptopis and furcilia stages occurred in higher abundances in the north with the exception of the shallow southern station 1271. Cladocerans were more numerous at the western stations (Sts. 1280/81, 1288, 1297) while the abundance of appendicularians seemed to be higher at the southern stations with highest numbers at St. 1265. Within the meroplankton, echinoderm larvae and polychaete larvae feature contrasting patterns. Echinoderm larvae occurred mainly at the southern stations while polychaetes prevailed at the northern ones. No clear pattern is obvious in bryozoans and cirripedes. 
(a)
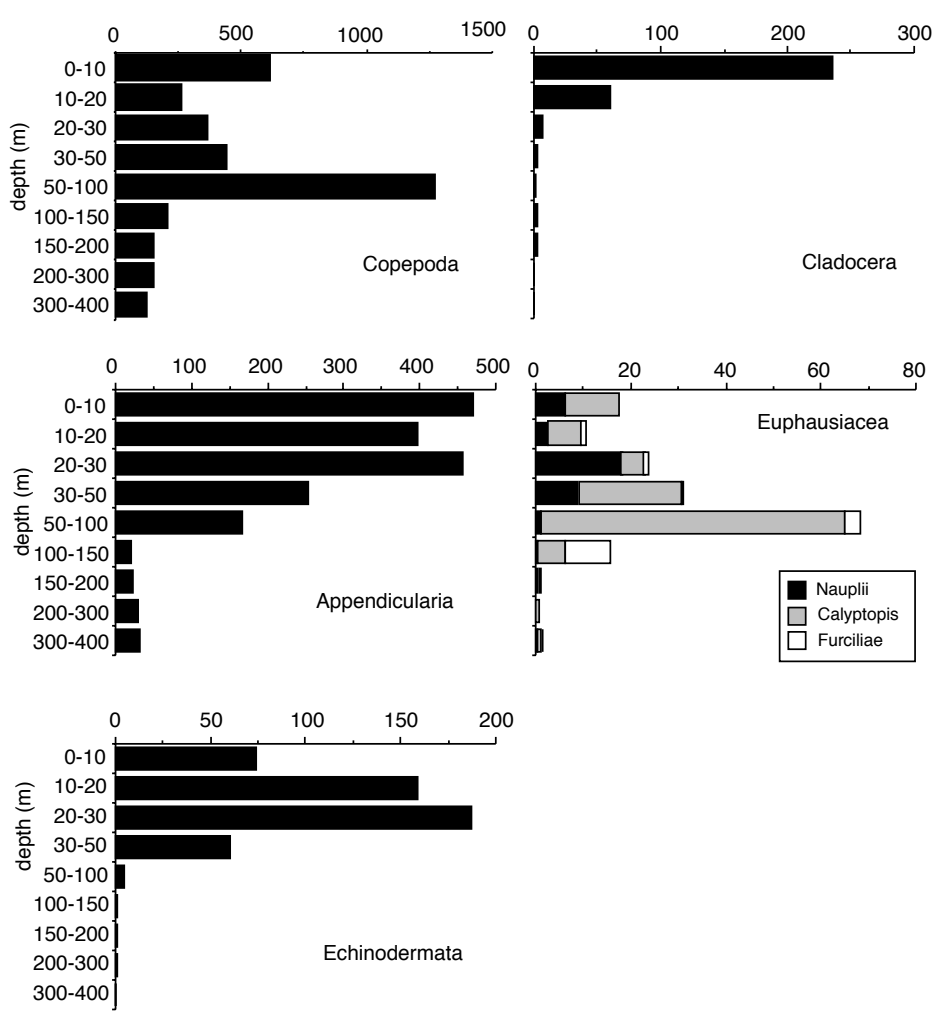

(b)
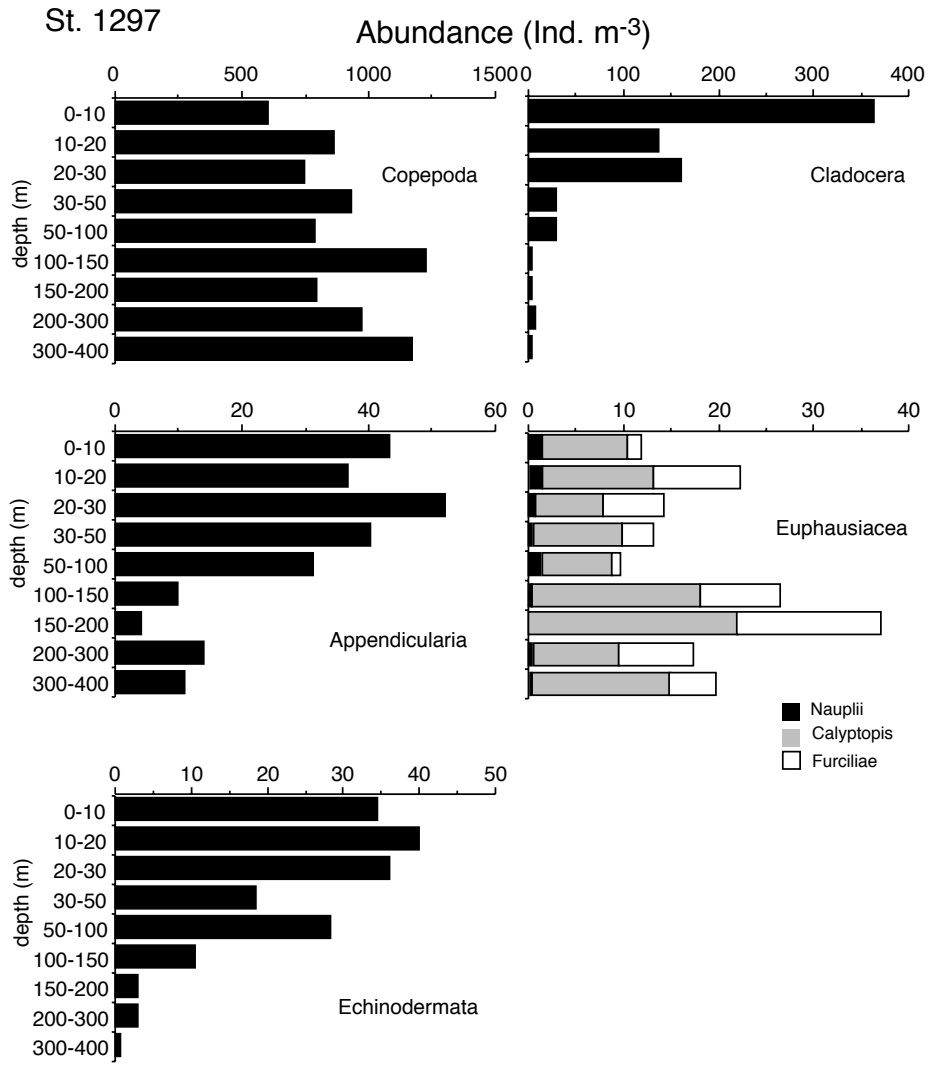

FIG. 4. - Vertical distribution of copepods, cladocerans, euphausiids, appendicularians, and echinoderm larvae at St. 1265 (a) and at St. 1297 (b). 
(a)
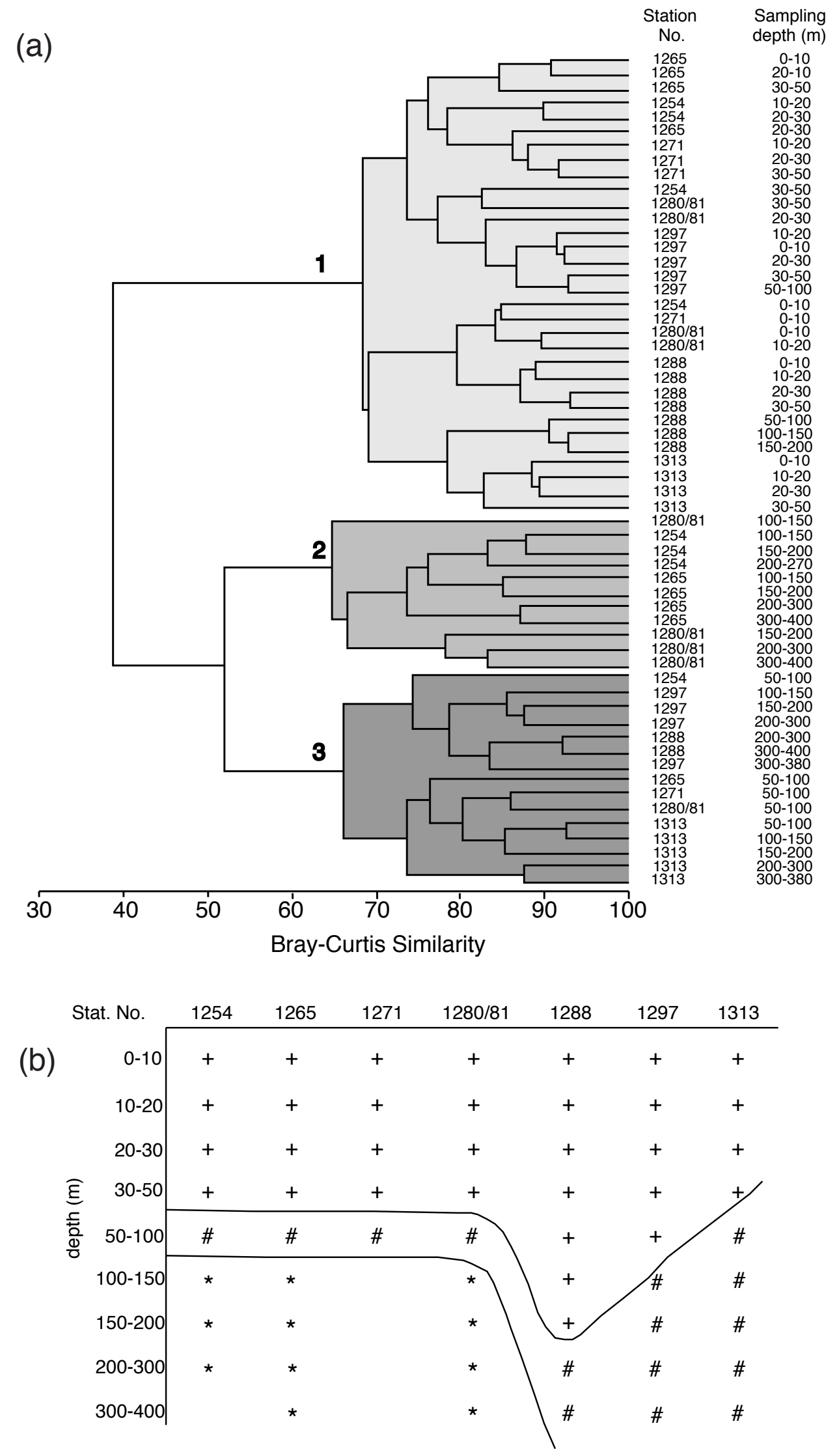

FIG . 5. - Cluster dendrogram showing classification of depths (a) and representation of depth clusters (b). 
The vertical distribution of abundance of the dominant groups is shown for two stations as examples for the northern (St. 1265, Fig. 4a) and southern region (St. 1297, Fig. 4b). At St. 1265 the bulk of copepods and euphausiids was located between 50 to $100 \mathrm{~m}$, while at St. 1297 both groups were distributed throughout the water column with higher concentrations in the middle and deeper layers. Euphausiid nauplii showed a preference for upper water layers and concentrated mainly between 0 and $100 \mathrm{~m}$. Calyptopis larvae occurred fairly regularly in the water column, and furcilia larvae were centered in middle water layers. Cladocerans gathered at both stations in the surface layer, whereas appendicularians were more widespread in the upper $100 \mathrm{~m}$. The larvae of benthic animals occurred in highest numbers in the upper 50 to $150 \mathrm{~m}$ (echinoderm larvae as an example in Fig. 4).

Cluster analysis of the mesozooplankton community composition reveals three groupings at the $65 \%$ similarity level (Fig. 5a), clearly separating between the upper (Cluster I) and the deeper water layers (Clusters II and III). Cluster II represents hauls from depths below $100 \mathrm{~m}$ at the southern stations. Deeper water samples at the northern stations are grouped in Cluster III together with the depth layer 50 to $100 \mathrm{~m}$ from the southern stations (Fig. 5b).

\section{DISCUSSION}

Copepods dominate in the entire study area. Similar studies in Antarctic waters near the Antarctic Peninsula and in the eastern Weddell Sea reveal similar results with regard to the dominance of copepods (60 to $99 \%$, Fevolden et al., 1985; Fransz et al., 1987; Hubold and Hempel, 1987; Boysen-Ennen and Piatkowski, 1988; Tholen, 1995). The higher abundances of copepods in the northern part of the Magellan region coincide with an unstratified or only weakly stratified water column (Antezana, 1999a). At these stations copepods are found throughout the water column without pronounced maxima values. In contrast, in the south the water column is stratified due to strong melting processes overlying warmer and saltier oceanic waters (Antezana, 1999a). It is interesting to note that while copepods are aggregated in the upper part of the water column, their densities never peak in the upper- most brackish water layers. A similar difference in vertical distribution is evident for euphausiids. In contrast, cladocerans, typical brackish water representatives, occur almost exclusively near the surface.

According to Antezana et al. (1996) chlorophyll maxima occur in the southern part of the Magellan region in subsurface layers below the pycnocline, and Gutt and Schikan (1996) frequently observed thick greenish mats at the sea floor. Together with the low abundances of holoplankton grazers (e.g. copepods) in the south this indicates that phytoplankton is not utilized efficiently by pelagic grazers. The spring bloom seems to rather sink to the bottom, where it serves as food for benthic organisms (Antezana, 1999b). The higher occurrence of meroplanktonic larvae (e.g. Echinodermata) at the southern stations could indeed be a response of increasing reproductive activities in the benthos caused by the higher food availibility after the sedimentation of the spring bloom.

With regard to the zooplankton and copepod community distribution, respectively, Guglielmo et al. (1991) and Mazzocchi and Ianora (1991) subdivided the Magellan Straits into four and two areas, respectively, each of which was defined by distinct differences in abundance and dominant species. In the present study, the surface zooplankton from all stations is grouped in one cluster, and hence, there is no geographical separation in the upper water layers, regardless of the observed differences in phytoplankton and hydrography (Antezana, 1999a, 1999b). The deeper water layers, by contrast, are separated between south and north, except for the 50-100 m depth layer of the southern stations, which forms part of the cluster grouping the deeper water samples from the northern part. This depth stratum in the south is located within or just below the pycnocline (Antezana, 1999 a), where copepods and euphausiids abound (see Fig. 4a). Detailed taxonomic analysis and stage differentiation is expected to yield further insight into the zooplankton communities and biogeography as well as the life cycles of dominant organisms.

\section{ACKNOWLEDGEMENTS}

Special thanks are due to Dr. Andreas Starmans, Alfred-Wegener-Institut, for his help with running the Cluster analysis. 


\section{REFERENCES}

Antezana, T. - 1999a. Hydrographic features of Magellan and Fuegian inland passages and adjacent Subantarctic waters. Sci. Mar., 63(Supl. 1): 23-34.

Antezana, T. - 1999b. Plankton of southern Chilean Fjords: trends and linkages. Sci. Mar., 63(Supl. 1): 69-80.

Antezana, T., L. Guglielmo and E. Ghirardelli. - 1992. Microbasins within the Strait of Magellan affecting zooplankton distribution. In: V.A. Gallardo, O. Ferretti and H.I. Moyano (eds.), Oceanografía en Antártica ENEA-PNRA, pp. 453-458.

Antezana, T., M. Hamamé, Y. Eissler and S. Jara. - 1996. Traits of phyto- and zooplankton from the Strait of Magellan to Beagle Channel on board RV „Victor Hensen“ leg 1 and 2, Oct-Nov 1994. Ber. Polarforsch. 190: 23-31.

Benassi, G., I. Ferrari, G. Gentile, P. Menozzi and K.G. McKenzie. - 1994. Ostracoda in zooplankton samples from the Straits of Magellan: 1991 cruise. Nat. Sc. Com. Ant., Magellan Cruise, Data Rep. III: 197-213.

Boysen-Ennen, E. and U. Piatkowski. - 1988. Meso- and macrozooplankton communities in the Weddell Sea, Antarctica. Polar Biol. 9: 17-35.

Fevolden, S., W. Hagen, I. Hempel, E. Mizdalski, S. Schnack, M. Spindler and Y. Xiao. - 1985. Zooplankton. Ber. Polarforsch. 25: 113-121.

Fransz, G., W. Hagen, I. Hempel, H.-P. Marschall, S. Marschall, E. Mizdalski and S. Schiel. - 1987. Zooplankton. Ber. Polarforsch. 39: 197-205.

Ghirardelli, E., L. Guglielmo and G. Zagami. - 1991. Chaetognaths in the Straits of Magellan (a preliminary note). Mem. Biol. Mar. Oceanogr. 19: 167-171.

Guglielmo, L., T. Antezana, G. Costanzo and G. Zagami. - 1991. Zooplankton communities in the Straits of Magellan. Mem. Biol. Mar. Ocean. 19: 157-161.

Guglielmo, L., A. Arena, G. Costanzo, N. Crescenti, S. Vanucci and G. Zagami. - 1993. Zooplankton ecology in the Straits of Magellan. Nat. Sc. Com.Ant., Magellan Cruise, Data Rep. II: 137250 .

Guglielmo, L., T. Antezana, N. Crescenti and A. Granata. - 1996. Amphipods, mysids, euphausiids, ostracods, chaetognaths. In: L. Guglielmo and A. Ianora (eds.), Atlas of Marine Zooplankton, Straits of Magellan, pp 1-279. Springer Verlag, Berlin.

Gutt, J. and T. Schickan. - 1996. Epibenthic communities analysed by underwater camera. Ber. Polarforsch. 190: 35-41.

Hubold, G. and I. Hempel. - 1986. Seasonal variability of zooplankton in the southern Weddell Sea. Meeresforschung 31: 185-192.

Mazzocchi, M.G. and A. Ianora. - 1991. A faunistic study of the copepod assemblages in the Straits of Magellan (FebruaryMarch 1991). Boll. Ocean. Teor. Appl. 9 (2-3): 163-177.

Mazzocchi, M.G., G. Zagami, A. Ianora, L. Guglielmo, N. Crescenti and J. Hure. - 1995. Copepods. In: L. Guglielmo and A. Ianora (eds.), Atlas of Marine Zooplankton, Straits of Magellan, pp 1-279. Springer Verlag, Berlin.

Pagès, F. - 1996. Preliminary results on the gelatinous zooplankton collected in the Magellan Strait. Ber. Polarforsch. 190: 34.

Tholen, K. - 1995. Die spätherbstliche Verbreitung von Zoo- und Phytoplankton im Weddellmeer, Antarktis. Master thesis, University of Bremen. $67 \mathrm{pp}$. 